\title{
Bakarat syndrome: A case study
}

\author{
Mra Aye ${ }^{1 *}$ and Jason Cabot ${ }^{2}$ \\ ${ }^{1}$ Department of Medicine, Melaka Manipal Medical College, Melaka 75150, Malaysia \\ ${ }^{2}$ Cancer Center of Guam, 633 Gov. Carlos Camacho Rd., B5, Tamuning, Guam 96913, USA
}

\begin{abstract}
Barakat syndrome (also known as HDR syndrome-hypoparathyroidism, sensorineural deafness and renal disease) an autosomal dominant disorder characterized by hypoparathyroidism, sensorineural deafness, and renal disease caused by mutation of the GATA3 gene located at chromosome 10p15, is very rare, with only about a dozen cases reported in the world literature. We report a case of 18-year-old with features consistent with Bakarat syndrome, which first presented with seizures at age two months and subsequently was diagnosed with bilateral high frequency sensorineural deafness and single kidney. Clinicians should be aware of rare inherited conditions when a patient presents with a constellation of signs and symptoms.
\end{abstract}

\section{Case presentation}

An 18-year-old male was admitted for asymptomatic hypercalcaemia (serum calcium $3.2 \mathrm{mmol} / \mathrm{L}$ ), a known case of congenital hypoparathyroidism who had been taking calcium lactate, calcium carbonate and ergocalciferol (vitamin D2). At birth he was seen to have right sided ptosis and was diagnosed with congenital hypoparathyroidism at age two months when he presented with generalised tonic clonic seizures. He was found to have bilateral high frequency sensorineural deafness at age four years and fitted with a hearing aid. He was also somewhat mentally retarded. No siblings or parental relatives had nerve deafness, hypoparathyroidism or renal diseases.

His mile stones were somewhat delayed as was academic performance. The right ptosis was partially corrected by surgeries at ages 5 and 7 years. At age 8 years, renal ultrasonography revealed absence of the left kidney and DMSA revealed a satisfactory functioning right kidney (Table 1). At age 12 years ergocalciferol was stopped (and he remained on oral calcium) but developed symptomatic hypocalcaemia and this drug was restarted. At age 17 he was noted to have elevated systolic blood pressure $137-139 \mathrm{mmHg}$ and renal ultrasonography (USG) revealed renal parenchymal disease in the sole kidney. $\mathrm{ECrCl}$ (Bedside Schwaz) was $65 \mathrm{ml} / \mathrm{min} / 1.73 \mathrm{~m}^{2}$. Serum urea and creatinine were within normal ranges (Table 2) as were serum $\mathrm{pH}$ and bicarbonate levels and 24-hour urinary protein was $0.14 \mathrm{~g} / \mathrm{L}$.

On physical examination, he was a well-developed, well-nourished young man with partial right ptosis who apart from a hearing aid and mild systolic hypertension $(138 / 82 \mathrm{mmHg}$ ) had no significant physical abnormalities. ECG was normal. Corrected serum Calcium was $3.0 \mathrm{mmol} / \mathrm{L}(2.16-2.50)$, inorganic phosphate was $1.22 \mathrm{mmol} / \mathrm{L}$ (0.76-1.65). Blood Sodium was 145 (136-145), Potassium 3.6 (3.6-5.1), Chloride $104 \mathrm{mmol} / \mathrm{L}$ (96-105). Blood urea was $8.8 \mathrm{mmol} / \mathrm{L}$ (3.20-8.20) and creatinine was $235 \mathrm{umol} / \mathrm{L}$ (82-115) (Table 2).

Calcium tablets and ergocalciferol were discontinued and $5 \%$ dextrose water two liters per day was administered as well as amlodipine $5 \mathrm{mg}$ per day orally. Since serum creatinine was elevated, USG kidney was repeated and showed parenchymal right renal disease and hydronephrosis with dilation of proximal right ureter. No stones or medullary calcinosis was noted. CT urogram revealed absence of left kidney, mild hydronephrosis of right kidney with normal ureter and no identifiable cause of hydronephrosis. Routine urinalysis was normal. Blood calcium had decreased to $2.6 \mathrm{mmol} / \mathrm{L}$ and ergocalciferol was reinstituted without addition calcium. Blood pressure was 120/80 mmHg upon the discharge. He was advised to avoid high phosphate diet and continue medial follow up

\section{Discussion}

The constellation of congenital hypoparathyroidism, sensorineural deafness and left renal agenesis in this patient is consistent with Bakarat syndrome [1-5], also known as HDR syndrome (for hypoparathyroid, (sensoineural) deafness, renal disease), an autosomal dominant disease [6]. Mutation in GATA3, a gene localised to chromosome region 10p14-15 has been detected in the families affected by the syndrome. GATA3 is a transcription factor involved in the embryonic development of parathyroid gland, kidney, inner ear, thymus and central nervous system [2]. Several mutations of GATA3 leads to a spectrum of HDR phenotypes [2]. Hypoparathyroidism is a consistent

Table 1. Imaging reports from childhood and current situation.

\begin{tabular}{|l|l|l|}
\hline Age 8 & DMSA & Well-functioning kidney \\
\hline Age 17 & USGKUB & $\begin{array}{l}\text { Single right kidney with renal parenchymal disease. No } \\
\text { obstructive uropathy }\end{array}$ \\
\hline $\begin{array}{l}\text { Age 18 } \\
9.03 .17\end{array}$ & USGKUB & $\begin{array}{l}\text { Single kidney with mild to moderate hydronephrosis proximal } \\
\text { hydroureter and renal parenchymal disease. Left kidney not } \\
\text { visualised }\end{array}$ \\
\hline $\begin{array}{l}\text { Age 18 } \\
10.03 .17\end{array}$ & $\begin{array}{l}\text { MSCT } \\
\text { urography }\end{array}$ & $\begin{array}{l}\text { Mild right hydronephrosis, cause unknown. Left kidney and } \\
\text { ureter not visualised }\end{array}$ \\
\hline
\end{tabular}

Correspondence to: Mra Aye, Department of Medicine, Melaka Manipal Medical College, Melaka 75150, Malaysia, Tel: +60-1955-45052; E-mail: mraaye@ hotmail.com

Key words: seizures, sensorineural deafness, renal agnesis, Bakarat syndrome, hypoparathyroidism, hypocalcemia

Received: August 04, 2017; Accepted: August 24, 2017; Published: August 28, 2017 
Table 2. Laboratory Results from childhood and current situation.

\begin{tabular}{|c|c|c|c|c|c|c|}
\hline AGE (years) & 5 & 14 & 17 & $\begin{array}{c}18 \\
6.03 .17\end{array}$ & $\begin{array}{c}18 \\
9.03 .17\end{array}$ & Normal range \\
\hline Calcium & $2.47 \mathrm{mmol} / \mathrm{L}$ & 2.02 & 2.30 & 3.0 & 2.60 & $2.16-2.50$ \\
\hline Inorganic phosphate & & 1.87 & 1.35 & 1.16 & 1.32 & $0.76-1.65$ \\
\hline Magnesium & & 0.67 & 0.77 & 0.88 & & $0.53-1.11$ \\
\hline \multicolumn{7}{|c|}{ Renal Profile } \\
\hline Urea & $4.0 \mathrm{mmol} / \mathrm{L}$ & 4.8 & 4 & 8.8 & 8.2 & $3.2-8.2$ \\
\hline Creatinine & $100 \mathrm{umol} / \mathrm{L}$ & 91 & 100 & 253 & 242 & $82-115$ \\
\hline \multicolumn{7}{|c|}{ Serum Electrolytes } \\
\hline Sodium & & 135 & & 145 & & $136-145$ \\
\hline Potassium & & 3.70 & & 3.6 & & $3.6-5.10$ \\
\hline Chloride & & 103 & & 104 & & $96-105$ \\
\hline \multicolumn{7}{|c|}{ Liver function test } \\
\hline Total Protein & & 80 & & $80 \mathrm{~g} / \mathrm{L}$ & & $97-82$ \\
\hline Total Bilirubin & & 4 & & $9 \mathrm{umol} / \mathrm{L}$ & & $<21$ \\
\hline Albumin & & 42 & & $46 \mathrm{~g} / \mathrm{L}$ & & $32-45$ \\
\hline Globulin & & & & $34 \mathrm{~g} / \mathrm{L}$ & & $25-36$ \\
\hline $\begin{array}{l}\text { Alanine Amino } \\
\text { Transferase }\end{array}$ & & 10 & & $34 \mathrm{U} / \mathrm{L}$ & & $10-49$ \\
\hline Alkaline Phosphatase & & 177 & & $133 \mathrm{U} / \mathrm{L}$ & & $45-129$ \\
\hline
\end{tabular}

feature in HDR syndrome occurring in $90 \%$ of patients but isolated hypoparathyroidism resulting from GATA3 haploinsufficiency has not been reported [4]. Patients may be asymptomatic despite marked hypocalcaemia. Symptomatic patients present with cramps, tetany cardiomyopathy or seizures [4]. Renal involvement is the most heterogenous feature of the triad. Hypoplasia, dysplasia, cystic kidneys, vesicouretric reflux, nephritic syndrome, pelvicalyceal abnormality, proteinuria, haematuria, proximal and distal renal tubular acidosis, nephrocalcinosis and renal failure have all been reported. Our patient had left renal agenesis, a consistent finding [2], and most probably left ureter agenesis [6-10].

The original patients described by Bakarat et al. [5] presented with proteinuria and progressed to steroid resistant nephrotic syndrome. However, our patient had no proteinuria on routine urinalysis but his renal function was deteriorating (creatinine $235 \mathrm{mmol} / \mathrm{L}$ ) and was possibly progressing to chronic renal failure as do most patients with the syndrome [8]. Early accurate diagnosis of renal disease has potential prognostic significance [11]. In our patient, renal anomaly was detected at age of 11 and impairment at age of 17 . Sensory neural deafness is the most consistent feature of Bakarat or HDR syndrome and is usually bilateral since birth. However, it may be asymmetric and varies for mild to profound and is worse at high frequencies. GATA3 haploinsifficiency predisposes the affected individuals to progressive morphological degeneration of the cochlea beginning with outer apex hair cells and ultimately affecting all hair and supporting cells in the entire cochlea [4]. Our patient was noted to be hearing impaired by his mother at age 4 years and was helped with hearing aids. Morphological and physiological abnormalities have been identified in the brain stem, cerebral cortex, outer and middle ear in GATA 3 haploinsufficiency [12]. Several non-triad features such as pyloric stenosis, polycystic ovaries, Mullirian duct abnormalities, congenital heart defects, recurrent cerebral infarcts, and hemimegalencephalopathy have been reported $[9,10,12,13]$. Our patient had none of these extra triad features but was born with complete right ptosis. Bakarat syndrome is not only rare but also difficult to diagnose or delayed due to the combination of features involving various systems. Renal involvement may not be appreciated as it is usually asymptomatic.

Our case demonstrates the diagnostic difficulty of Bakarat syndrome, which may become evident at any age. Therefore, one should test for sensory neural deafness and renal anomalies when a patient presents with seizures due to hypoparathyroidism. Likewise, when isolated bilateral sensorineural deafness, rare in children, is present, one should think of a potential systemic disease or syndrome. Renal anomalies, one of the features, have prognostic importance and early therapy might prevent and slow renal damage.

\section{Conclusion}

Bakarat syndrome is relatively rare and diagnosis difficult if the attending physicians are unaware of the syndrome.

\section{References}

1. Mejia JD, Cervantes L, Puerta H, Bauer M, Diaz A (2014) Neonatal diagnosis of a patient with hypoparathyroidism, sensorineural deafness and renal dysplasia (HDR) syndrome associated with cerebral infarction. J Pediatr Endocr Met 27: 961-965. [Crossref]

2. Sau T, Chatterjee A, Ghosh K, Dey S (2013) Seizure, deafness and renal agenesis: A rare case of Barakat syndrome. Ann Indian Acad Neurol 16: 91-93. [Crossref]

3. Maleki N, Bashardoust B, Alamdari MI, Tavosi Z (2013) Seizure, deafness, and renal failure: A case of barakat syndrome. hindawi publishing corporation. Case Rep Nephrol: 4

4. Upadhyay J, Steenkamp DW, Milunsky J (2013) The syndrome of hypoparathyroidism, Deafness, and Renal anomalies. HDR syndrome. Endocr Pract 19: 1035-1036. [Crossref]

5. Bakarat AY, D'Albora, Martin MM, Jose PA (1977) Familial nephrosis, nerve deafness, and hypoparathyroidism. J Pediatr 91: 61-64. [Crossref]

6. Bilous R.W, Musty G, Parkinson DB, Thakker RV, Coulthard MG, et al. (1992) Autosomal dominant familial hypoparathyroidism, sensorineural deafness, and renal dysplasia. N Engl J Med 327: 1069-1074.

7. Van Esch H, Groenen P, Nesbit MA, Schuffenhauer S, Lichtner P, et al. (2000) GATA 3 haplo-insufficiency cause human HDR syndrome. Nature 406: 419-422. [Crossref]

8. Muroya K, Hasegawa T, Ito Y, Nagai T, Isotani H, et al. (2001) GATA 3 abnormalities and the phenotype spectrum of HDR syndrome. J Med Genet 38: 374-380. [Crossref]

9. Taslipinar A, Kebapeilar L, Kutlu M, Sahin M, Aydogdu A, et al. (2008) HDR syndrome (hypoparathyrodism, sensorineural deafness and renal disease) accompanied by renal tubular acidosis and endocrine abnormalities. Intern Med 47: 1003-1007. [Crossref]

10. Kato Y, Wada N, Numata A, Kakijaki H (2007) Case of hypoparathyrodism, deafness and renal dysplasia (HDR) syndrome associated with nephrocalcinosis and distal renal tubular acidosis. Int J Urol 14: 440-442. [Crossref]

11. Melis D. Genesio R, Boemio P, Del Giudice E, Cappuccio G, et al. (2012) Clinical description of a patient carrying the smallest reported deletion involving $10 \mathrm{p} 14$ region. Am J Med Genet A 158A: 832-835. [Crossref] 
12. Nesbit MA, Bowl MR, Harding B, Ali A, Ayala A, et al. (2004) Characterization of GATA3 mutation in the hypoparathyroidism, deafness, and renal dysplasia (HDR) syndrome. J Biol Chem 279: 22624-2234. [Crossref]
13. Van der Wees J, van Looij MA, de Ruiter MM, Elias H, van der Burg H, et al. (2004) Hearing loss following GATA 3 haploinsufficiency is caused by cochlear disorder. Neurobiol Dis 16: 169-178. [Crossref]

Copyright: (C2017 Aye M. This is an open-access article distributed under the terms of the Creative Commons Attribution License, which permits unrestricted use, distribution, and reproduction in any medium, provided the original author and source are credited. 